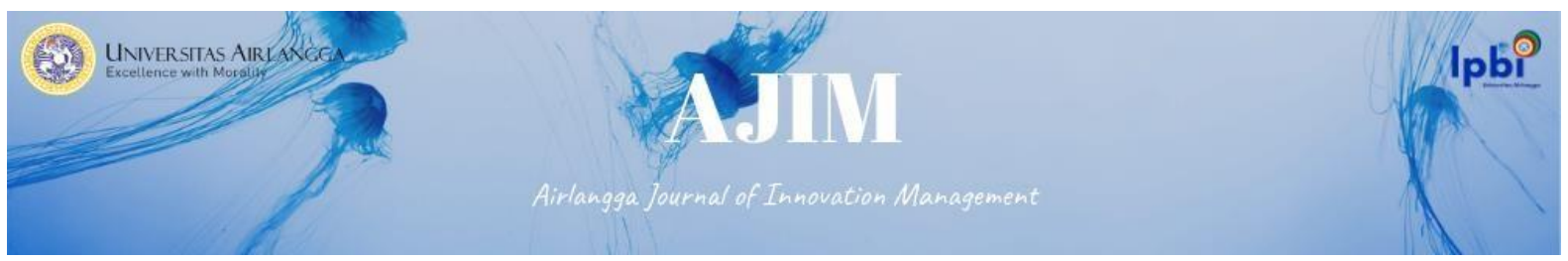

Vol. 2 No.1 Juni 2021

e-ISSN: 2722-5062

DOI : 10.20473/ajim.vvii.26613

\title{
MODERATING EFFECT OF MANAGERIAL AND PROFSSIONAL ASSISTANCE ON INNOVATION STRATEGY AND ACADEMIC SPIN-OFF MANAGEMENT
}

\author{
Oscar Chrismadian Noventa \\ Universitas Atma Jaya Yogyakarta \\ Corresponding e-mail : oscar.chrismadian@uajy.ac.id
}

\begin{abstract}
The university is required to commercialize the results of research and knowledge of the university through academic spin-off. Academic spin-off benefit for stimulating the economy, creating job growth and innovation. However, academic spin-off find difficulty in offering products and services to the market because of the lack of knowledge related to managerial and resource management. Means commonly used to overcome this obstacle is to establish a business incubator in the form of a centralized facility that provides access, support and university policy. Business Incubator helps new academic spin-off stand to better understand the market and to provide guidance in the initial phase of the establishment of academic spin-off. This study aimed to examine the moderating effect of the assistance provided university business incubator in the election strategy of innovation and academic spin-off performance. The study was conducted at 76 academic spin-off in Yogyakarta and Semarang. In this study developed a theoretical model by proposing three hypotheses to be tested using regression analysis. The survey results revealed that academic spinoff conduct exploitation strategy proved a positive influence on the performance of academic spin-off. Instead, academic spin-off conduct proven exploration strategy negatively affect academicspin-off performance. Furthermore, managerial and professional assistance as moderating variables are proven to be able to strengthen the relationship between innovation strategy and academic spin-off performance.
\end{abstract}

Keywords: Academic Spin-off, Managerial and Professional Assistance, Academic SpinoffPerformance

\section{Introduction.}

University has a strategy that focuses on research, teaching and service. In this case, universities are required to be able to commercialize their research results and knowledge by creating academic spin-off (Fini et al., 2011). Universities that are able to commercialize research through academic spinoff will provide benefits for boosting economy, creating job growth and innovation (Phan et al., 2005). Academic spin-off responds to market needs by offering innovative products and services. However, academic spin-off often find any difficulties to offer its products and services to market due to a lack of managerial knowledge and resource management. A common tool used to overcome this obstacle is to 


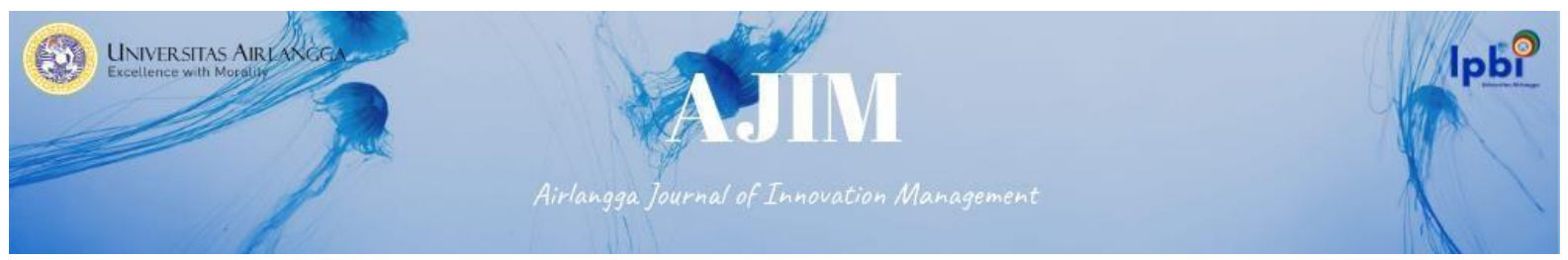

establish a business incubator in form of a centralized facility that provides access, support and university policies (Bergek \& Norrman, 2008; Löfsten \& Lindelöf, 2005).

Business Incubators are very useful in helping to overcome failure rate that often occurs in new academic establishments. Business incubator helps newly established academic establishments better understand market and provides assistance in initial phase of academic establishments. Bruneel (2012) explains that incubators not only offer tangible services such as buildings and workspaces but also intangible services, such as training, business coaching, and access to capital, which are part of the incubator's efforts to help ensure the survival and growth of academic spin-off. This importance of business incubator role become urgency to build university business incubator, so that universities can be involved and offer effective ways to stimulate and support innovation and economic growth (Soetanto \& Jack, 2016).

This study attempts to examine effect of managerial and professional assistance provided by university business incubators in Central Java and Yogyakarta on strategy selection and performance by academic spin-off. This study uses a sample of academic spin-off that has been incubated by a university business incubator by looking at managerial and professional assistance. Based on the explanation above, this study examines moderating effect of managerial and professional assistance provided by university business incubators on selection of innovation strategies and the performance of academic spin-off.

\section{Literature Review \\ Exploration and Exploitation Strategy}

March (1991) and Hitt et al. (2011) describes two innovation strategies, namely exploration and exploitation. Exploration is a strategy when academic spin-off pursues new knowledge, abilities and skills in developing new products or services to be able to capture new market opportunities. Meanwhile, exploitation is a strategy when academic spin-off develops ability to increase excellence, increase knowledge and develop products and services to serve an existing market. Exploration is also said to be a process of searching for what may be known, and exploitation as development of what is already known (Levinthal \& March, 1993).

\section{Knowledge-Based View Theory}

Knowledge-based view is a view that focuses on knowledge as a strategic and important resource for a company (Nonaka \& Takeuchi, 1995). Knowledge-based companies place more emphasis on internal resources, such as knowledge of consumers; process efficiency; knowledge possessed by workers; as a key to achieving a sustainable competitive advantage (Davenport and Prusak, 1997; Teece, 1998). Grant, (1996) describes a company as an institution that creates and integrates knowledge, because characteristics of knowledge are about production. This knowledge is embedded in corporate entities in form of employees, organizational culture, systems and documents, policies, and organizational culture (Alavi \& Leidner, 2001). Knowledge-Based View can be used to explain processes that occur during incubation of academic spin-off as well as how knowledge application in assisting development of academic spin-off (Hackett \& Dilts, 2004).

\section{University Business Incubator}

University business incubator is an institution that provides facilities in developing academic spin-off by providing facilities in form of; 1) space loans, 2) providing assistance services to reduce costs, 3) professional and managerial assistance, 4) access to start-up capital (Brooks, 1986). Payumo et al. (2014) explained that support from university business incubators is one of determining factors in business development. Hacket and Dilts (2004) argue that university business incubators share office 


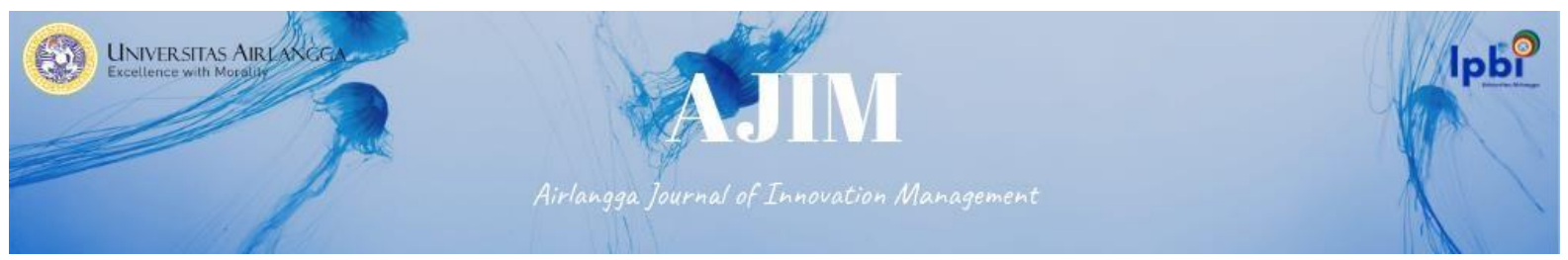

space facilities provided for academic spin-off in form of strategies and value additions that can help business development. The university's business incubator links resources aims to facilitating development of academic spin-off. So that university business incubator can be defined as an institution that plays a role in creation of academic spin-off by providing resource assistance in form of; a) building space, b) network support, c) consultation with managerial and professional, d) providing access to capital. University business incubators are referred to as change agents because of their support for development of academic spin-off during periods of market and technological development. The university business incubator helps academic spin-off in initial process of starting a business. University business incubators are agents of change through their support of academic spin-off during periods of economic downturn or technological development. Academic spin-off helps through stabilizing local economy as well as providing new economic activities based on small businesses. Academic spin-off helps create jobs and reduce unemployment. Thus university business incubators are a reasonable strategy for developing economies if they can cumulatively help survival and accelerate growth of academic spin-off (Campbell, 1989).

\section{Academic spin-off}

Academic spin-off has specific criteria, like, 1) a company resulting from commercialization of research conducted by universities (Callan, 2001), 2) university has a stake in academic spin-off (Lockett \& Wright, 2005), 3) founders of academic spin-off are alumni, lecturers and staff from university (Wright et al., 2006). The formation of academic spin-off begins with research activities carried out by university. After that, market identification is carried out to look for opportunities and resources (Vohara et al., 2004). Furthermore, Vanalest et al, (2006) explain academic spin-off to make prototypes to commercialize research results. After prototype development is complete, a new organizational structure is formed and funding proposals are submitted to investors.

\section{Exploitation Strategy and Exploration Strategy}

Voss and Voss (2013) describe academic spin-off that focuses on effective exploration or exploitation in achieving goals when organizational strategy has high consensus, focus and clarity. Exploration in field of technology and markets are more directed at creating new markets while exploitation of technology and markets leads to creating advantages in existing markets. Research conducted by (Yalcinkaya et al., 2007; Christensen \& Bower, 1996; Soetanto and Geenhuizen, 2018) shows that fully exploiting current market will encourage additional product development, while exploiting current technology will help create better support for current market. Meanwhile, exploration in technology and market domains enables academic spin-off to create new markets. Exploration of new technologies through innovation enables academic spin-off to identify opportunities to develop products or services in new markets. Based on arguments from previous studies, it is suspected that exploitation and exploration strategies have a positive impact on of academic spin-off performance.

\section{Managerial and Professional Assistance}

Academic spin-off requires knowledge of management to overcome difficulties in managing uncertainty and simultaneously managing different management tasks (Grimaldi \& Grandi, 2005). To reduce difficulties that can hinder growth of academic spin-off, university business incubators provide managerial and professional assistance such as training and mentoring to improve entrepreneurial skills and provide access to more specialized professionals (Bergek \& Norrman, 2008). Academic spin-off must compete with lack of managerial knowledge and skills, so managerial and professional assistance can increase growth of academic spin-off. Managerial and professional assistance such as training and mentoring can improve internal ability of academic spin-off and enable academic spin-off in identifying and taking advantage of opportunities during exploratory activities. results of above study indicate that 


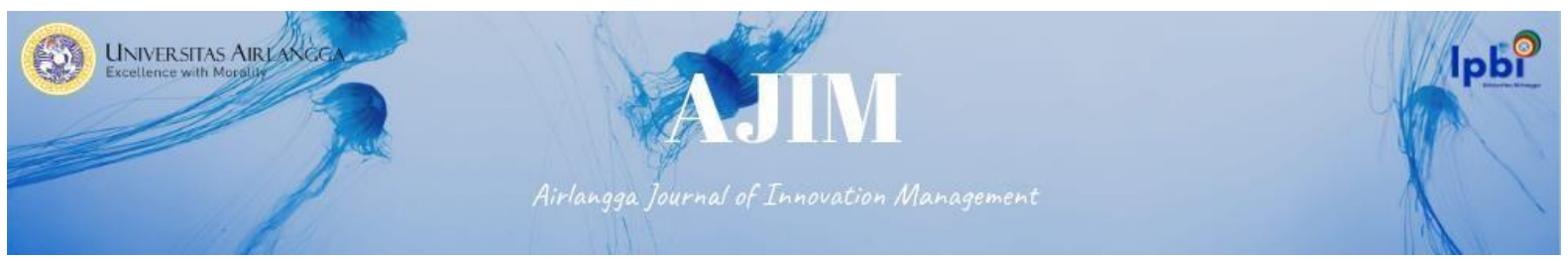

there is a positive moderating effect of managerial and professional assistance on relationship of exploration and exploitation strategies to academic spin-off performance.

\section{Research Framework}

From previous research, it can be concluded that network, managerial and professional assistance, as well as business development moderate relationship between selection of exploitation strategies and exploration strategies on academic spin-off performance. From description above, research framework can be formulated as follows
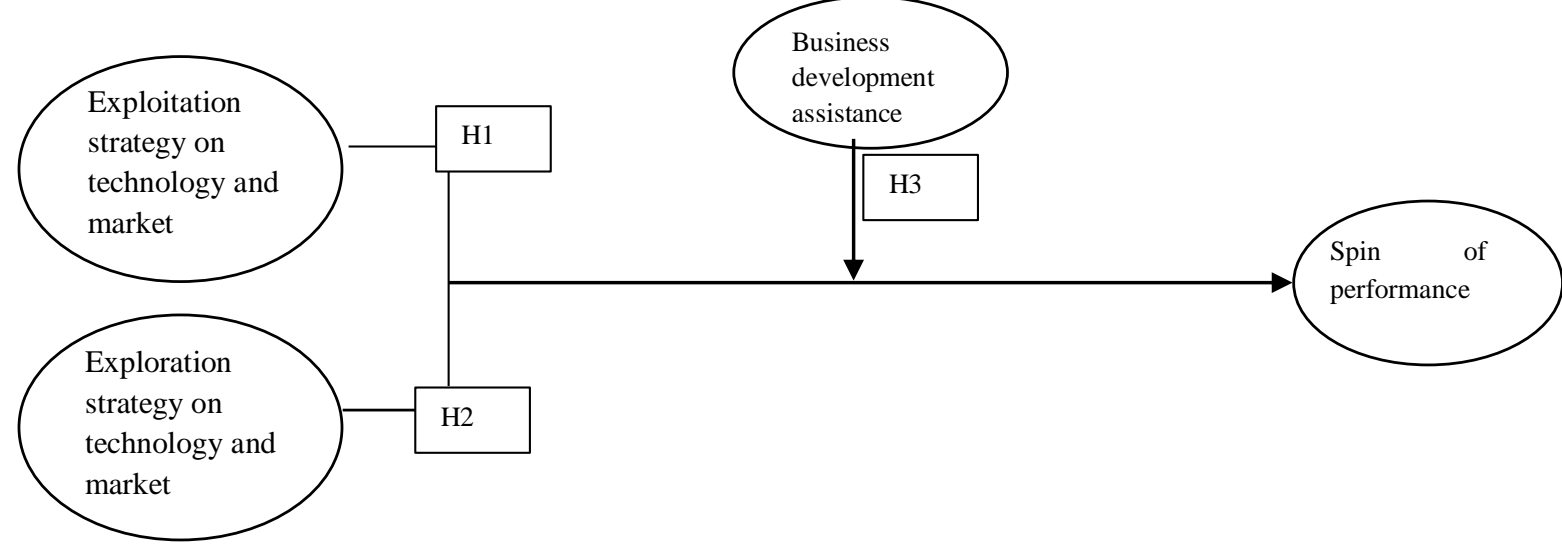

Source: Author (2021)

\section{Figure 1 Research Framework}

\section{Method}

\section{Population and Sample}

Population in this study is academic spin-off in Central Java and Yogyakarta with unit of analysis, namely company. Population selection in Indonesia was carried out because research context on university business incubators role on university-based academic spin-off performance is rarely studied in Indonesia. Targeted sampling method was chosen because researcher took samples by setting certain criteria according to research objectives (Cooper \& Schindler, 2014). Criterias used in this research are, first, academic spin-off has met conditions of commercialization of knowledge and technology created by university; second, at least students, alumni or academic staff must be actively involved in academic spin-off. Based on website of Indonesian Business Incubation Association or Asosiasi Inkubasi Bisnis Indonesia (AIBI), research location was carried out at university business incubators in Yogyakarta and Semarang. The choice of these two cities is because many universities in two cities already have business incubators that have been running and have fostered academic spin-off. The number of samples used in this study were 76 academic spin-off.

\section{Operational Definition and Measurement of Variables Managerial and Professional Assistance}

Managerial and professional assistance is assistance provided by business incubators to academic spin-off in form of management training, business and consultation with business incubator managers (Swierczek 1992 in Hayati et al., 2017). All managerial and professional assistance items were measured using a Likert scale. 


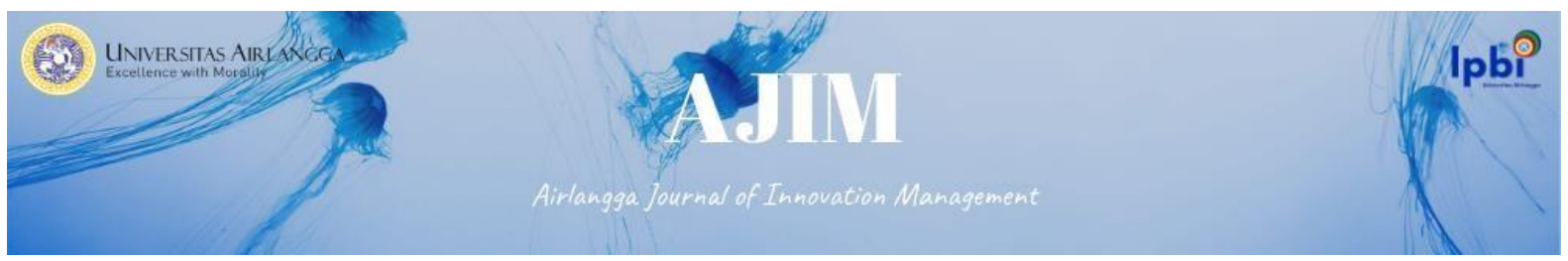

\section{Innovation Strategy}

Innovation strategy is measured using three items with five Likert scales for each of four strategies, namely technology exploration, technology exploitation, market exploration, market exploitation (Soetanto \& Jack 2016). All innovation strategy questions were measured using a Likert scale.

\section{Academic Independent Performance}

Performance is a variable that can be measured and is also a commonly used construct to measure an impact of innovation. In this study, academic spin-off performance is measured in a non-financial perspective. All statement items are measured using a Likert scale

\section{Test Measurement Instrument}

\section{Validity test}

According to Cooper and Schindler (2014), validity is the level that indicates an extent to which a test is able to measure what it wants to measure. The researcher uses internal validity to show instrument's ability to measure what should be measured from a concept. Confirmatory Factor Analysis (CFA) is used to determine convergent validity. The CFA assessment is carried out by looking at factor loadings value with a value of 0.3 to 0.4 which indicates minimal consideration is accepted as an indicator of a valid instrument.

\section{Reliability Test}

According to Hair et al. (2014), reliability test aims to analyze internal consistency of a construct by looking at Cronbach's alpha value in researching multi-item measurements. The reliability of consistency between indicators can be explained by using Cronbach alpha coefficient (Hair et al., 2014). The magnitude of Cronbach alpha coefficient with Cronbach alpha value 0.7 and getting closer to 1 indicates that reliability is acceptable. Higher Cronbach alpha coefficient value, shows reliability of measurement instrument (Hair et al., 2014).

\section{Data Analysis Method}

Hypothesis testing in this study using regression analysis. This analysis technique was chosen because it is in accordance with Baron \& Kenny (1986) that measurement of hypotheses involving moderating variables can be done using regression. Hypothesis testing in this study uses two stages. The first is to examine direct effect of innovation strategy on academic spin-off performance using simple regression. The second is to test an help of a business incubator as a moderating variable on relationship between innovation strategy and academic spin-off performance using moderated regression analysis (MRA).

\section{Validity Test Result}

Validity test in this study used a confirmatory factor analysis (CFA) technique using SPSS 16.0 for windows software. Validity testing was carried out on four (4) variables in this study, namely exploitation strategy, exploration strategy, academic spin-off performance, managerial and professional assistance, and with statement items as many as 25 items. The statement item is said to be valid if KMO and Barlett's Test values are above 0.5 . The factor loading value is above 0.5 . Perfectly extracted items with no multiple loading factor values in different groups.

\section{Tabel 1 KMO dan Bartlett's Test Result}

\begin{tabular}{|l|l|}
\hline Kaiser-Meyer-Olkin Measure of Sampling Adequacy & 0,703 \\
\hline Bartlett's Test of Sphericity & 0,000 \\
\hline
\end{tabular}

Source: Processed Primary Data (2021) 


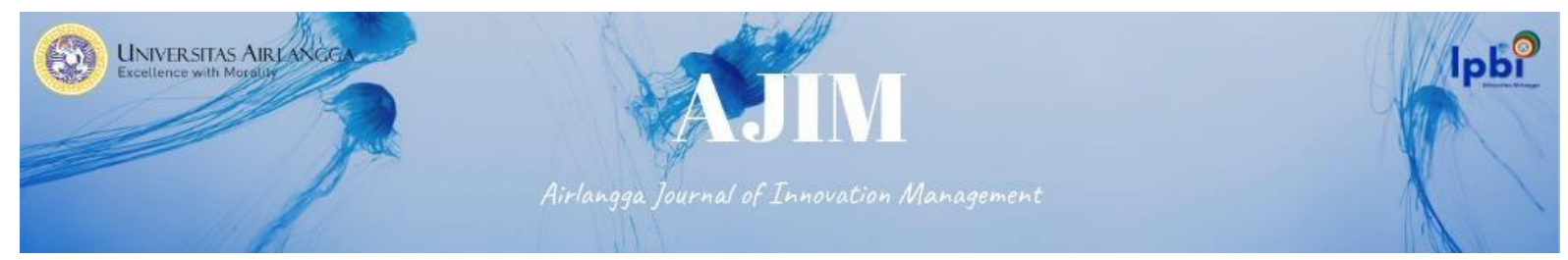

Table 1 shows a value of KMO Measure of Sampling Adequacy (MSA) in this study of 0.703, which has a value above 0.5 . Barlett test value with significant Chi-squares at 0.000 indicates that this instrument has met valid requirements.

Table 2 Results of Rotated Component Matrix Test

\begin{tabular}{|c|c|c|c|c|}
\hline Item & Komponen 1 & Komponen 2 & Komponen 3 & Komponen 4 \\
\hline SE11 & 0,575 & & & \\
\hline SE12 & 0,741 & & & \\
\hline SE13 & 0,814 & & & \\
\hline SE21 & 0,839 & & & \\
\hline SE22 & 0,735 & & & \\
\hline SE23 & 0.624 & & & \\
\hline SP11 & & 0,745 & & \\
\hline SP12 & & 0,754 & & \\
\hline SP13 & & 0,756 & & \\
\hline SP21 & & 0,662 & & \\
\hline SP23 & & 0,681 & & \\
\hline KP1 & & & 0,802 & \\
\hline KP2 & & & 0,626 & \\
\hline KP3 & & & 0,783 & \\
\hline KP4 & & & 0,660 & \\
\hline BMP1 & & & & 0,708 \\
\hline BMP2 & & & & 0,829 \\
\hline BMP3 & & & & 0,756 \\
\hline BMP4 & & & & 0.599 \\
\hline BMP5 & & & & 0.779 \\
\hline BMP7 & & & & 0,671 \\
\hline BMP8 & & & & 0,641 \\
\hline
\end{tabular}

Source: Processed Primary Data (2021)

Validity testing is carried out in several stages of testing, namely by removing items that are not grouped, have double values or have no value. Based on results of last stage of validity testing, it shows that all items have been extracted perfectly and have a factor loading value above 0.5 by removing question items BMP6 and BMP9. So it can be concluded that all existing items are valid because they meet requirements of validity test.

\section{Reliability Test Results}

Reliability testing aims to determine consistency of question items used in study. Reliability test in this study used Cronbach's Alpha method for each variable with help of SPSS 16.0 for windows. 


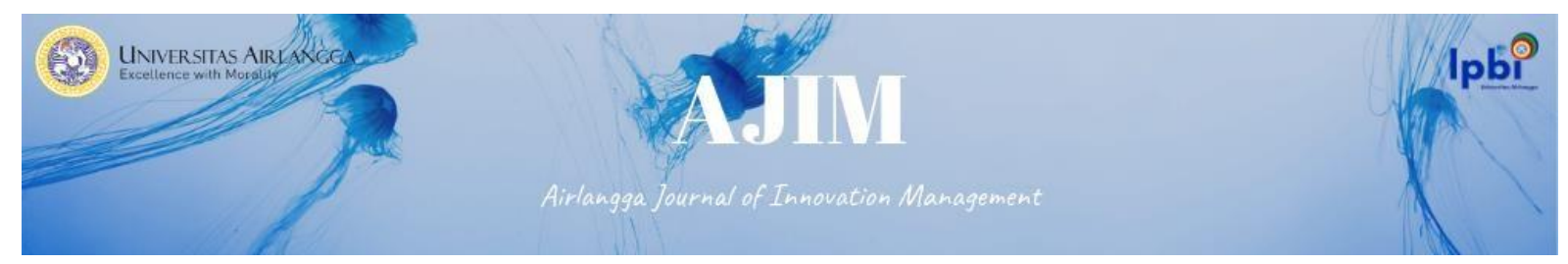

Table 3. Cronbach's Alpha Test Results

\begin{tabular}{|l|l|l|}
\hline No. & Variable & Cronbach's Alpha \\
\hline 1. & Exploitation Strategy & 0,837 \\
\hline 2. & Exploration Strategy & 0,793 \\
\hline 3. & Academic Spin-off Performance & 0,785 \\
\hline 4. & Managerial dan Professional Assistance & 0,882 \\
\hline
\end{tabular}

Source: Processed Primary Data (2021)

Table 4.8 shows that reliability level of six variables in this study, namely exploitation strategy, exploration strategy, academic spin-off performance, business development assistance, managerial and professional assistance.

\section{Hypothesis Test Results}

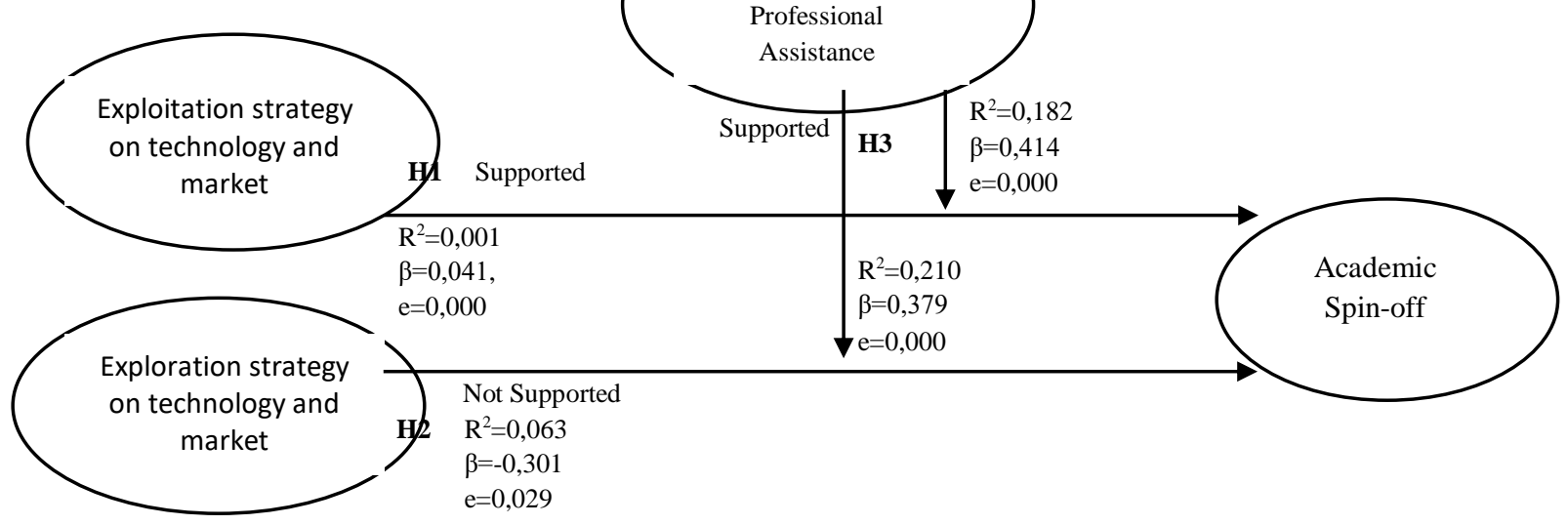

Figure 2 Hypothesis Test Results

Effect of Technology Exploitation Strategy and Market Exploitation on Academic spin-off Performance

Hypothesis testing results show that there is a positive and significant relationship between the variables spin-off exploitation strategies with academic performance, meaning that the results supported hypothesis 1 . However, the results of the regression coefficient indicate that the variable exploration strategy is only able to partly explain the variable spin-off academic performance of $0.01 \%$. This is due to the founder or manager of the academic spinoff feel there has been no significant change in its business. This is shown in KP1 and KP3 descriptive statistics which have an average value that is lower on the aspects of partnership and market share. Though academic spin-off as an emerging business needs to establish a lot of collaboration with external parties. However, when an academic spin-off gets help moderating influence networking and business development assistance which has a correlation coefficient of 0.076 and 0.056 . Values fairly high correlation coefficient indicates that the university business incubator has been to provide guidance and facilitate academic spin-off 


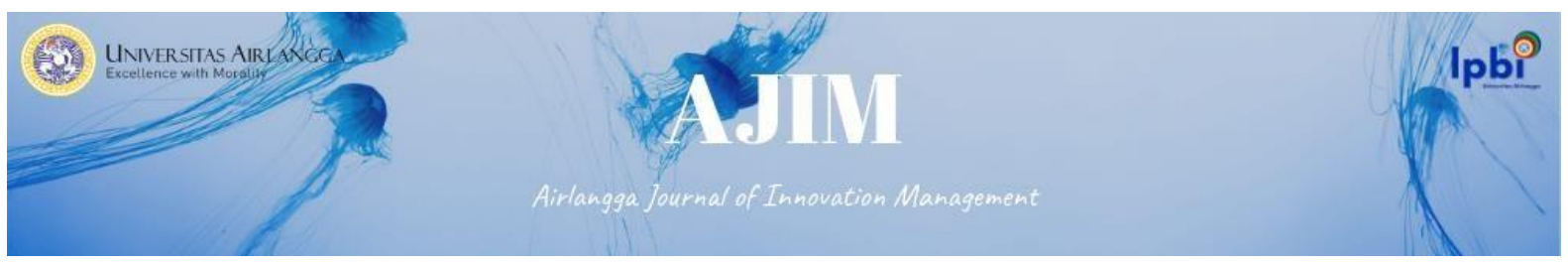

network. Thus, the postincubation academic spin-off feels a significant impact on business development.

Similar research results with the results of previous research and voss voss (2013), which shows spin-offacademic focus on one of either exploitation or exploration strategy is more effective in achieving the objectives of academic spinoff. Yalcinkaya et al. (2007); Soetanto and Geenhuizen (2019) also showed that when the academic spin-off exploits the market will be able to develop additional products and exploit the technology will be able to assist in creating a product.

\section{The Influence of Technology Exploration Strategy and Market Exploration on Academic spin- off Performance}

Hypothesis result testing indicate that there is a negative and significant relationship between exploration strategy and academic spin-off performance, meaning that results of hypothesis 2 are not supported. The negative and significant relationship between exploration strategy and academic spinoff performance is caused by relatively short observation year, namely academic spin-off which has been completed incubating in 2016, 2017, and 2018. experimenting on products and researching new markets.

Smith and Tushman (2005); Cao et al (2009) who showed that exploratory strategy showed a negative influence on academic spin-off performance because it takes a longer time for organizations to adapt to technology and markets. An academic self-reliance that explores new ideas shows less definite results and a more diffuse effect than when an academic self-employment exploits an existing technology or market. Exploration Strategy has far-reaching implications on performance as well because realization of strategy takes a long time. Academic establishments that carry out exploration strategies need to invest their funds in conducting product experiments and looking for approaches to new markets. Therefore, academic spin-off performance will be better if academic spin-off focuses on improving existing products to capture opportunities in new markets.

Exploration strategy has far-reaching implications on performance as well because strategy realization takes a long time. Academic establishments that carry out exploration strategies need to invest their funds in conducting product experiments and looking for approaches to new markets. Therefore, academic spin-off performance will be better if academic spin-off focuses on improving existing products to capture opportunities in new markets.

\section{Effect of Exploitation or Exploration Strategy on Academic spin-off Performance with Managerial and Professional Assistance as Moderation}

Result of hypothesis testing indicate that managerial and professional assistance moderates effect of exploitation or exploration strategies on academic spin-off performance. These results indicate that academic spin-off, whether using exploitation strategies or exploration will experience an increase in performance when getting managerial and professional assistance, meaning that hypothesis 4 is supported. Results of determination coefficient indicate that addition of moderating variables for managerial and professional assistance is able to provide additional explanations for effect of exploitation or exploration strategies on academic spin-off performance. Moderating effect of managerial and professional assistance is more on exploration strategies than exploitation strategies. Results of this study are in line with previous studies conducted by Bergek and Norrman (2008) and Slater et al. (2014) which shows that managerial and professional assistance can improve internal ability 


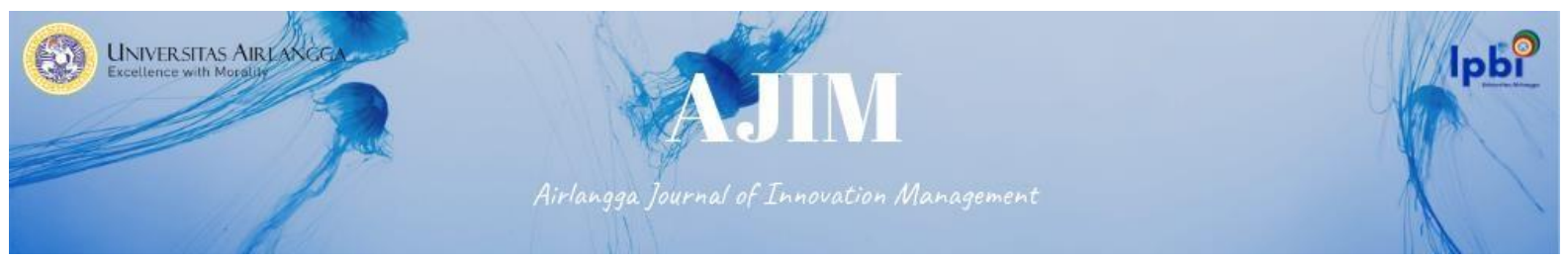

of academic spin-off so that academic spin-off is able to identify and take advantage of opportunities well. Assistance is provided in form of training and mentoring in business planning that can increase competitiveness and survival of academic spin-off (Löfsten et al., 2016). Specialized managerial and professional assistance has become part of curriculum material created by Indonesian Association of Business Incubators (AIBI), so that all university business incubators in this study provide managerial and professional assistance which can further assist academic spin-off in improving their performance.

\section{Conclusion}

The exploitation strategy has a positive and significant relationship on academic spin-off performance. The exploration strategy has a negative and significant relationship on academic spin-off performance. An academic self-reliance that explores new ideas shows less definite results and a more diffuse effect than when an academic self-reliance exploits existing technologies and markets. Managerial and professional assistance has been shown to positively and significantly moderate effect of exploitation or exploration strategies on academic spin-off performance.

Theoretically, the findings in this study provide evidence that moderating effect of managerial and professional assistance can strengthen relationship between exploitation or exploration strategies on academic spin-off performance. Academic spin-off that engages in exploratory strategies requires longer years of observation to show improved performance. Academic spin-off that carried out exploration or exploitation strategies showed results that had less effect on performance. This is because academic spin-off is still trying to find an effective combination of exploitation and exploration.

Practical contributions for founders or managers of academic spin-off should pay attention to right combination of strategies between exploitation and exploration. Academic establishments can better profit by leveraging existing products to sell them in new markets. Managers of business incubators should pay more attention to role of networking and business development. Assistance in business development, both in management of legality and financial statements, will make academic spin-off easier to measure for the value of its validation by potential investors. Business incubators must also be more active in providing their business networks to increase collaboration between academic spin-off and various related parties and agencies.

\section{Limitations and Suggestions}

The sample in this research is specific to university business incubators, so it has not been able to capture how is the influence of business development assistance, managerial and professional assistance, and business development assistance on government and private business incubators. Future research can look at an effect of these three grants on government and private business incubators.

Results of this study indicate that academic spin-off that carries out a single strategy, either exploration or exploitation, shows results that have less effect on performance. This happens because academic spin-off is still trying to find an effective combination of exploitation and exploration. Therefore, further research can see how influence of ambidexterity from exploitation and exploration can be seen to be able to see best combination of strategies that can be used by academic spin-off.

In this study, influence of managerial and professional assistance as a moderating variable has an influence on academic spin-off performance. However, it is also necessary to look at influence of other variables that can strengthen moderating effect of exploitation or exploration strategies on academic spin-off performance, for example adding reputation of human resources or social networks as variables that can strengthen academic spin-off performance. 


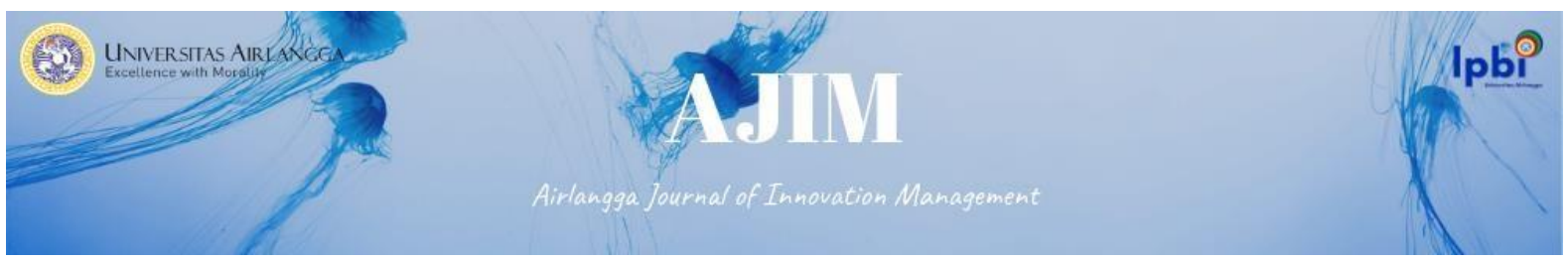

\section{Reference}

Baron, R. M., \& Kenny, D. A. (1986). The moderator-mediator variable distinction in social psychological research: Conceptual, strategic and statistical considerations. Journal of Personality and Social Psychology, 51, 1173- 1182.

Bergek, A., \& Norrman, C. (2008). Incubator best practice: A framework. Technovation, 28(12), 20-28.

Bruneel, J., Ratinho, T., Clarysse, B., \& Groen, A. (2012). The Evolution of Business Incubators: Comparing demand and supply of business incubation services across different incubator generations. Technovation, 32(2), 110-121.

Callan, J., \& Connell, M. (2001). Query-based sampling of text databases. ACM Transactions on Information Systems (TOIS), 19(2), 97-130.

Cao, Q., Gedajlovic, E., Zhang, H., 2009. Unpacking organizational ambidexterity: dimensions, contingencies, and synergistic effects. Organ. Sci. 20 (4), 781- 796.

Christensen, C. M., \& Bower, J. L. (1996). Customer power, strategic investment, and the failure of leading firms. Strategic management journal, 17(3), 197- 218.

Cooper, D. R., \& Schindler, P. S. (2014). Business Research Methods. Data Preparation and Description.

Fini, R., Grimaldi, R., Santoni, S., \& Sobrero, M. (2011). Complements or substitutes? The role of universities and local context in supporting the creation of academic spin-offs. Research Policy, 40(8), 1113-1127.

Grimaldi, R., \& Grandi, A. (2005). Business incubators and new venture creation: an assessment of incubating models. Technovation, 25(2), 111-121.

Hackett, S. M., \& Dilts, D. M. (2004). A systematic review of business incubation research. The Journal of Technology Transfer, 29(1), 55-82.

Hair, J. F. J., Black, W. C., Babin, B. J., \& Anderson, R. E. (2014). Multivariate Data Analysis. Seventh Edition Prentice Hall.

Hitt, M. A., Ireland, R. D., Sirmon, D. G., \& Trahms, C. A. (2011). Strategic entrepreneurship: creating value for individuals, organizations, and society. Academy of management perspectives, 25(2), 57-75.

Levinthal, D. A., \& March, J. G. (1993). The myopia of learning. Strategic management journal, 14(S2), 95-112.

Lockett, A., Siegel, D., Wright, M., \& Ensley, M. D. (2005). The creation of spin- off firms at public research institutions: Managerial and policy implications. Research policy, 34(7), 981-993. 


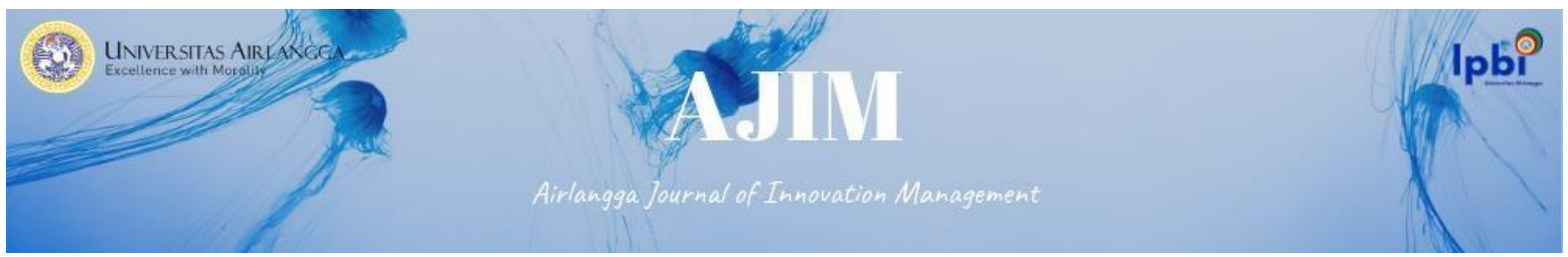

Löfsten, H., \& Lindelöf, P. (2005). R\&D networks and product innovation patterns - academic and non-academic new technology-based firms on Science Parks. Technovation, 25(9), 1025-1037.

March, J. G. (1991). Exploration and exploitation in organizational learning.Organization science, 2(1), 71-87.

Nonaka, I. \& Takeuchi, H., (1995). The Knowledge-Creating Company: How Japanese Companies Create the Dynamics of Inovation. New York: Oxford University Press.

Phan, P. H., Siegel, D. S., \& Wright, M. (2005). Science parks and incubators: observations, synthesis and future research. Journal of business venturing, 20(2), 165-182.

Slater, S. F., Mohr, J. J., \& Sengupta, S. (2014). Radical product innovation capability: Literature review, synthesis, and illustrative research propositions. Journal of Product Innovation Management, 31(3), 552-566.

Soetanto, D., \& Jack, S. (2016). The impact of university-based incubation support on the innovation strategy of academic spin-offs. Technovation, 50, 25-40.

Soetanto, D., \& van Geenhuizen, M. (2019). Life after incubation: The impact of entrepreneurial universities on the long-term performance of their spin-offs. Technological Forecasting and Social Change, 141, 263-276.

Vanaelst, I., Clarysse, B., Wright, M., Lockett, A., Moray, N., \& S'Jegers, R. (2006). Entrepreneurial team development in academic spinouts: An examination of team heterogeneity. Entrepreneurship Theory and Practice, 30(2), 249-271.

Voss, G. B., \& Voss, Z. G. (2013). Strategic ambidexterity in small and medium- sized enterprises: Implementing exploration and exploitation in product and market domains. Organization Science, 24(5), 1459-1477.

Yalcinkaya, G., Calantone, R. J., \& Griffith, D. A. (2007). An examination of exploration and exploitation capabilities: Implications for product innovation and market performance. Journal of International Marketing, 15(4), 63-9 